\title{
COMMENT
}

Received 9 May 2017 | Accepted 13 Jul 2017 | Published 22 Aug 2017

DOI: 10.1057 /palcomms.2017.85

\section{The role of indigenous peoples in combating climate change}

\author{
Linda Etchart ${ }^{1}$
}

\begin{abstract}
Until the twenty-first century, indigenous peoples were viewed as victims of the effects of climate change, rather than as agents of environmental conservation. Representatives of indigenous peoples have in fact since 2008 been actively seeking a role in contributing to combating climate change through their participation in international environmental conferences, as well as by means of activism and political engagement at local and national levels. Using examples from the Amazonian region in the east of Ecuador, home to indigenous communities such as the Huaorani, Sápara and Sarayaku Kichwa originary peoples, this article argues that indigenous peoples, particularly forest dwellers, have a dual role in combating climate change. First, colonized forest peoples have continued to resist the occupation and deforestation of lands they have lived in for centuries; second, a number of indigenous forest communities have since the 1990s become aware of their responsibility to protect the forests in the interests of combating climate change. They have recognized the potential for their having decision-making power at a local and global level that may contribute to saving the planet. In the last 10 years indigenous peoples' representatives have been collectively engaged in lobbying for inclusion in intergovernmental climate change negotiations and to have decision-making power at the United Nations. This comment calls for international support from governments and civil society from both North and South, at the United Nations and at other international fora, to uphold the rights of indigenous peoples -enshrined in international law-who wish to prevent incursions into their territory for the extraction of fossil fuels. Moreover, it calls on governments, (I)NGOs, and private companies engaged in the extractive industries, and in other processes of modernization and development, to respect the right of indigenous peoples not to develop and to choose for themselves the level of their integration into the global economy and polity. The choice not to develop, not to have access to the modern world through roads, for example, is itself a contribution to protecting the rainforest and reducing greenhouse gas emissions. This article draws on existing scholarly literature on the Ecuadorian Amazonian indigenous peoples, primary research among Huaorani and Sarayaku Kichwa communities of Eastern Ecuador 2016-2017, and documents from the United Nations Permanent Forum on Indigenous Issues (UNPFII) 26 April-6 May 2017. The aim is to provide policymakers, and those to whom they are accountable, with knowledge and understanding to improve decision-making in the interests of citizens and the environment.
\end{abstract}

\footnotetext{
${ }^{1}$ Department of Geography, Birkbeck, University of London, London, UK
} 
T he territories of the world's 370 million indigenous peoples cover $24 \%$ of land worldwide, and contain $80 \%$ of the world's biodiversity (Sobrevila, 2008; IPS, 2017). Indigenous peoples occupy the sites of precious natural resources, and it is they who protect forests vulnerable to the encroachment of modernity. If indigenous communities are successful in maintaining control of their territories and can preserve their customs, their traditions and their way of life, they may be able to resist development and the deleterious consequences of modernity.

Many indigenous peoples-the definition of indigenous peoples is contested, but for the purpose of this article I shall use the shorthand definition - the "uncolonized"-have lived in a sustainable way for millennia, feeding themselves without damaging the environment, in "Harmony with Nature" (First Principle of the Rio Declaration 1992). It is precisely this knowledge that has protected their environment, and which may be useful in terms of their participation in global governance of the environment; before their incorporation into the modern world their contribution to environmental conservation was inadvertent, as continues to be the case for those indigenous people who choose to live in voluntary isolation. Others, such as the Huaorani peoples of the Ecuadorian Amazon who became selectively incorporated into modernity in the second half of the twentieth century (Lucero, 2008), have become aware of their role in combating climate change only since the 1990s. Their consciousness of their deliberative role has been enhanced by the recognition of their rights under the Ecuadorian Constitution of 2008, which gives them status equal to local government (Yashar, 2005; High, 2015).

\section{The history of Indigenous Peoples' efforts to be involved in global Climate Agreements}

Following the adoption in 1997 of the Kyoto Protocol to reduce global greenhouse gas emissions, Indigenous Peoples' representatives began to push for engagement in climate change agreements, but they have continued to be side-lined. One of the sources of their frustration has been that the grounds for their involvement were that indigenous communities were affected by climate change, giving them the status of victims, rather than their being viewed as potential actors in the quest to combat climate change.

By 2004, their involvement was given support by the United Nations Framework Convention on Climate Change (UNFCCC) -the international environmental treaty negotiated at the Earth Summit in Rio de Janeiro from 3 to 14 June 1992-which entered into force on 21 March 1994.

Indigenous peoples' efforts to protect themselves and the environment were slow to capture media attention in both North and South. In its December 2015 report, the Indigenous Peoples' Centre for Documentation, Research and Information (DOCIP) reiterated the link between climate change and the rights of indigenous peoples, stating that "Indigenous peoples have been making this link for several decades, taking centre stage in its promotion" (DOCIP, 2015: 3).

Since 2013, indigenous representatives have been meeting at international conferences and other fora that have enabled them to join forces in solidarity to call for their rights to be respected under national and international law on the grounds of both human rights and protection of the environment. The International Labour Organization (ILO) has been a consistent and vocal support of indigenous peoples, notably having secured in 1989 the "Convention concerning Indigenous and Tribal Peoples" that entered into force on 5 September 1991 and which laid the basis for the United Nations Declaration on the Rights of Indigenous Peoples (UNDRIP) of 2007.
The Rio+20 Outcome Document of 2012 stressed the importance of indigenous peoples in the achievement of sustainable development and the importance of UNDRIP in the context of the implementation of sustainable development strategies. This followed the disappointment of indigenous peoples having been excluded from the Millennium Development Goals (MDGs) in September 2000, which led to their insistence in being including in the drafting of the Sustainable Development Goals (SDGs) of 2015.

Indigenous groups were also frustrated at the way in which the 2007 UNDRIP was omitted from the texts of global climate change agreements, and in particular their exclusion from the main events of the COP21 Climate Summit in Paris in December 2015, at which representatives of indigenous communities staged their own side-events and established their own platform, the Indigenous Peoples Forum on Climate Change (IIPFCC).

At the Sixteenth Session of the the UNPFII, 24 April to 5 May 2017 in New York, the ILO once again declared that indigenous peoples had a critical role at the forefront of climate action. The ILO's 2016 Technical Note "Indigenous Peoples and Climate Change: from Victims to Change Agents through Decent Work" identifies indigenous peoples as essential to the success of policies and measures directed towards mitigating, and adapting to, climate change (ILO, 2016).

At the UNPFII 2017 conference, indigenous peoples presented themselves as key players in the achievement of SDGs 13, 14 and 15 , which include combating climate change, sustainably managing forests and halting biodiversity loss (UNPFII, 2017).

As can been seen from indigenous peoples' own publications, they take their own involvement in combating climate change as vital to the task. Their interest in preventing the violation of their territorial rights by enterprises engaged in fossil fuel exploration and extraction which have in the past also contaminated their water sources and violated their human rights, coincides with the interest of environment groups and of some UN member state governments in their attempts to reduce greenhouse gas emissions and global warming. It should be a win-win situation. Protecting indigenous peoples' wellbeing, their culture and traditions, the forests and biodiversity by means of the prohibition of oil exploration and extraction on and from indigenous peoples' territory contributes to the pressures to find alternative sources of energy.

\section{Oil extraction and greenhouse gas emissions: the case of Ecuador}

Deforestation is a major cause of carbon emissions, and forests themselves act as a carbon sink. The World Resources Institute claimed in 2014 that community forests around the globe of 513 million hectares store 37 billion tonnes of carbon, 29 times the annual carbon footprint of the world's passenger vehicles-carbon that must be retained on the earth (Stevens et al., 2014a, b).

In Ecuador alone, 39\% of greenhouse gas emissions come from deforestation and other land use changes resulting from oil extraction. Much of the tree cover loss occurs in the Ecuadorian Amazon region, where indigenous communities live in the rainforest, from which they derive their livelihoods. Their territories are in theory protected, designated as belonging to the community and not to individuals. The indigenous inhabitants are entitled by the Ecuadorian Constitution of 2008 to exclude others from their lands (Yashar, 2005: 243).

Ensuring indigenous inhabitants' rights over their territories is not sufficient to prevent incursion by the extractive industries, however. This is because, even though they are protected by their own Constitution and by the UNDRIP (2007), to which the government of Ecuador is a signatory, and which grants them 
rights over their territory, there is a caveat. By Ecuadorian law and by the escape clauses with the UNDRIP, including within the commitment to Free Prior and Informed Consent, the territorial landowners are not owners of the mineral resources in the subsoil, which means that oil and minerals can be extracted without their permission.

Despite this, the rights of the Sarayaku Kichwa people were ruled by the Inter-American Court of Human Rights in 2012 to have been violated by the activities of an oil company. A 12 -yearlong legal struggle resulted in the imposition of a fine on the Ecuadorian government, a public apology and the cessation of oil exploration on Sarayaku land (Inter-American Court of Human Rights, 2012). To date, their territory remains secure.

The landmark ruling in favour of the Sarayaku Kichwa by the Inter-American Court of Human Rights did not deter oil exploration and drilling on other communities' Indigenous Territories in Ecuador, not least in the Yasuní National Park, one of the most biodiverse places on earth (Vidal, 2011). The Tiputini $\mathrm{C}$ well platform near the Peruvian border is expected to be the first of nearly 200 wells below the Ishpingo Tambococha Tiputini block. In 2016, President Correa's government sold oil exploration rights on 500,000 acres of forest adjoining the Yasuní National Park for US\$80 million to a consortium of Chinese state-owned oil companies (Vidal, 2016).

\section{Direct action on the part of indigenous communities to defend their territories against oil extraction}

In 2017, while discussions continued at a snail's pace at the level of intergovernmental organizations and their member states, indigenous peoples such as the Huaorani and Sápara peoplesand their neighbours and cousins the Tagaere and Taromenane, who live in voluntary isolation-watched as the Chinese oil drillers encroached upon their lands (Tagliani, 2004). Their numbers being small-there are just over 500 Sápara people leftindividual indigenous groups have little power on their own against armed state or private armies-yet individual indigenous groups are prepared to confront military force and give up their lives (Etchart, 2017).

Governments and private corporations engaged in oil extraction are, therefore, having to confront damaging publicity in the global media and in diplomatic circles, in addition to violent resistance on the ground by communities adversely affected by logging and oil spills. Pressure from UN agencies, other international and regional organizations, from local and international courts-brings alive the possibility of deterring the purchases of more oil concessions in Ecuador by Chinese companies, particularly in the light of the Chinese government's moves in 2017 to take the lead in global Climate Talks.

Small symbolic gestures-when witnessed and recorded by the international press-cause sufficient embarrassment to oil prospectors that they have in the past withdrawn and gone elsewhere. Only concerted efforts on the part of determined actors at all levels, transnational, international, national and local, be they state or non-governmental, will make a difference. As Alicia Cawiya, vice-president of the Huaorani people, commented: "The territory is not just for the indigenous people, it is for the world. Everyone must support it and fight for these territories. Yasuní is important for life on earth" (quoted in Etchart, 2017).

Both the concept of citizenship and that of international law are being redefined (Yashar, 2005; Boyle and Chinkin, 2007) and, with them, the procedures, processes and functioning of the United Nations and its allied institutions. The plan being discussed within the UN in 2017 was that Indigenous Peoples' status at the UN would be no lower than that of NGOs accredited to the UN's Economic and Social Council.
Indigenous peoples are for the moment a force to be reckoned with. In some countries and regions, including in the USA, their numbers are increasing, though their languages may be disappearing (King, 2016). In Ecuador, only five individuals continue to speak the Sápara language, for example (Gloria Ushigua, personal communication 2017). The last of the world's "uncontacted tribes"-communities living in voluntary isolation-are being brought into the fold of modern society. Those on the frontiers of the rainforest grapple with the challenges of retaining their land and their identity while experiencing the lure of the city, which will soon or later entice them away. It will not be long before there will be no one left to defend the trees against loggers and prospectors. Much depends on whether roads are built: once one road is constructed, side-roads emerge, creating a "fishbone" effect such that within a few years, large areas of forest disappear and with it, the forest peoples (Eriberto Gualinga, personal communication (August, 2016)).

It is the moment, therefore, for the world's most powerful institutions - public and private-to support indigenous peoples' efforts to be incorporated into decision-making with regard to measures that will secure their rights and which will contribute to combating climate change. It is also the moment for the United Nations member states to take action to implement the agreements to which they are signatories and in the fulfilment of which indigenous peoples have a role to play.

\section{References}

Boyle A and Chinkin C (2007) The Making of International Law. Oxford University Press: Oxford.

Chevron Tóxico 'A Rainforest Chernobyl'. chevrontoxico.com/about/rainforestchernobyl.

DOCIP (Indigenous Peoples' Centre for Documentation, Research and Information). (2015) 'Sustainable Development Goals and the post-2015 development agenda: Indigenous peoples' fight not to be left behind' http://cendoc.docip.org/ collect/upd_en/index/assoc/HASHd175.dir/Upd109_eng.pdf.

Etchart L (2017) 'One woman against Big Oil and Patriarchy', New Internationalist no 500, March.

High C (2015) Victims and Warriors: Violence, history and memory in Amazonia University of Edinburgh. University of Illinois Press: Urbana, IL, http://www. research.ed.ac.uk/portal/en/publications/victims-and-warriors.

Inter-American Court of Human Rights. (2012) Case of the Kichwa Indigenous People of Sarayaku v. Ecuador Judgment of June 27, http://corteidh.or.cr/docs/ casos/articulos/seriec_245_ing.pdf.

International Labor Organization (ILO). (2016) Indigenous Peoples and Climate Change http://www.un.org/esa/socdev/unpfii/documents/2016/Docs-updates/ Technical-Note_Indigenous-Peoples_ILO.pdf.

IPS (2017) Indigenous Peoples Lands Guard 80 Per Cent of World's Biodiversity. IPS News. www.ipsnews.net/2017/02/indigenous-peoples-lands-guard-80-percent-of-worlds-biodiversity.

King JCH (2016) Blood and Land. Penguin Allen Lane: London.

Lucero JA (2008) Struggles of Voice: The Politics of Indigenous Representation in the Andes. University of Pittsburgh Press: Pittsburgh, PA.

Stevens C, Winterbottom R, Reytar K and Strong A (2014a) 'Ecuador Shows Why Communities and the Climate Need Strong Forest Rights' 19 September. http:// www.wri.org/blog/2014/09/ecuador-shows-why-communities-and-climateneed-strong-forest-rights.

Stevens C, Winterbottom R, Reytar K and Strong A (2014b) 'Securing Rights, Combating Climate Change How Strengthening Community Forest Rights Mitigates Climate Change', World Resources Institute www.wri.org/sites/ default/files/securingrights_executive_summary.pdf.

Sobrevila C (2008) The role of indigenous peoples in biodiversity conservation: the natural but often forgotten partners. World Bank: Washington, DC.

Tagliani L (2004) También el sol muere: Cuatro años con los Huaorani. Vicariato Apostólico de Aguarico: Quito.

UNPFII Sixteenth Session 24 April to 5 May 2017 Indigenous Speakers in Permanent Forum Decry Governmental Abuse of Traditional Lands, Natural Resources, Urge Respect for Self-Governing Systems https://www.un.org/press/ en/2017/hr5353.doc.htm.

UN Draft Resolution by the General Assembly on Enabling the Participation of Indigenous Peoples' Representatives and Institutions in Meetings of Relevant United Nations Bodies on Issues Affecting Them. Zero Draft 19 April 2017 "Clean Version" presented by Peter Thomson, Professor James Anaya, Ambassador Kai Sauer Permanent Representative of Finland Ambassador 
Martha Ama Akyaa Permanent Representative of Ghana to the United Nations, Dr Claire Charters.

Vidal J (2011) 'Four months to save the world's last great wilderness from the "oil curse"' Guardian 13 August.

Vidal J (2016) 'Ecuador Drills for Oil on Edge of Pristine Rainforest in Yasuní: First of 200 wells drilled close to controversial block of forest known to have two of the last tribes living in isolation'. Guardian, 4 April.

Yashar DJ (2005) Contesting Citizenship in Latin America: The Rise of Indigenous Movements and the Postliberal Challenge. Cambridge University Press: Cambridge.

\section{Additional information}

Competing interests: The author declares that there are no competing financial interests.

Reprints and permission information is available at http://www.palgrave-journals.com/ $\mathrm{pal} /$ authors/rights_and_permissions.html
How to cite this article: Etchart L (2017) The role of indigenous peoples in combating climate change. Palgrave Communications. 3:17085 doi: 10.1057/palcomms.2017.85.

Publisher's note: Springer Nature remains neutral with regard to jurisdictional claims in published maps and institutional affiliations.

\section{(c) (i)}

This work is licensed under a Creative Commons Attribution 4.0 International License. The images or other third party material in this article are included in the article's Creative Commons license, unless indicated otherwise in the credit line; if the material is not included under the Creative Commons license, users will need to obtain permission from the license holder to reproduce the material. To view a copy of this license, visit http://creativecommons.org/licenses/by/4.0/

(C) The Author(s) 2017 